\title{
ADVANTAGES OF PRE-CLEARANCE PROCEDURES IN MARITIME TRANSPORT
}

\author{
MAURO BERNACCHI ${ }^{1} \&$ ALESSANDRO TORELLO ${ }^{2}$ \\ ${ }^{1}$ University for Foreigners of Perugia, Italy \\ ${ }^{2}$ University of Macerata, Italy
}

\begin{abstract}
During the various stages of importation, economic operators have to bear in mind the impact of possible delays because of customs clearance operations and bureaucratic rules requiring compliance. Analysis of the time necessary to clear goods is a crucial issue for integrated logistics systems, since the current international trade scenario is increasingly based on time-related models (e.g. lead-time analysis, time-based competitive strategy). This paper examines the economic advantages of the application of maritime pre-clearance mechanisms in the European Union. Customs authorities are informed about the customs procedures to apply before vessels arrive at the port of destination. Therefore, thanks to the declaration-at-sea procedures, goods can be cleared at sea before containers are unloaded from sea-going vessels; consequently, the transit time of containers inside ports can be reduced and the handling operations at harbours faster. In addition, pre-clearance operations can be more effective if those economic operators who are involved in the international movement of goods, and who are part of worldwide supply chain mechanisms (e.g. manufacturers, freight forwarders, terminal operators, stevedores, warehouse keepers and clearance agents), have obtained AEO status (Authorised Economic Operator). The AEO status allows economic operators to achieve a list of tangible and concrete benefits in terms of customs procedure simplification and a reduced number of safety-related customs controls. In conclusion, faster release of goods at borders is beneficial for both customs administrations and businesses, enabling customs authorities to process more transactions without delay and traders to improve their level of competitiveness in international markets.

Keywords: AEO, containerized traffic, customs-related operations, e-customs, pre-clearing.
\end{abstract}

\section{INTRODUCTION}

The global integrated logistics system is increasingly based on time-related models, such as lead-time analysis or time-based competitive strategy, and on the improvement and simplification of customs procedures: e-customs and the replacement of paper-format customs procedures with electronic procedures is an excellent example [1], [2]. However, importing goods still means dealing with customs clearance operations and complying with byzantine bureaucratic rules, thus customs clearance operations and the release of goods are often a major obstacle for economic operators [3].

The Revised Kyoto Convention (RKC), updating the previous convention on the simplification and harmonization of customs procedures (the Kyoto Convention of 1973-1974) and entering into force in 2006, is currently the main international trade facilitation customs convention. As stated in the preamble and in Article 2 of the RKC, one of the principal purposes of that Convention is the elimination of "divergence between the Customs procedures and practices of Contracting Parties that can hamper international trade and other international exchanges".

The World Customs Organization (WCO), encouraging the harmonization of customs procedures (i.e. best practises), requires that economic operators, acting at any level of the logistics supply chain, must take into serious consideration issues pertaining to customs compliance, especially in terms of safety. In June 2005 the WCO Council adopted the SAFE Framework of Standards to Secure and Facilitate Global Trade in order to guarantee security to the international supply chain [4]. The four core elements on which the SAFE 
Framework is based are an attempt to strengthen the level of safety inside the supply chain. Specifically, the four core elements deal with (I) the harmonization of the advance electronic cargo information requirements on inbound, outbound and transit shipments; (II) the reduction of security threats through accurate risk analysis; (III) the use of non-intrusive apparatus and equipment for cargo scanning (i.e. X-ray machines and radiation detectors) to inspect high-risk containers; (IV) tangible benefits for business operators being able to comply with supply chain security standards and best practices [5]. In this regard, the SOLAS Container Weight Verification Requirement (Verified Gross Mass - VGM) discipline, which became effective in July 2016, has an important impact on the risk-based approach and the need of inspecting high-risk containers. In fact, the main target of the VGM regulation is the verification of the weight of packed containers by requiring that packed containers' gross mass must be verified before loading containers onto vessels [6] (see also IMO Resolution MSC.380(94), adopted on 21 November 2014).

The single window [7] is the principal instrument, which has been implemented in the EU in order to harmonise and simplify the administrative procedures pertaining to maritime transport [8], [9]. The positive consequence of the development of an effective single window network is the facilitation of the movement of goods, as the exchange of information between governmental authorities and economic operators is faster and less problematic. The single window simplification policy can be matched with Directive 2014/100/EU, also known as Vessel Traffic Monitoring and Information System (VTMIS Directive), which aims to establish an information system to control the movement of vessels and to enhance environmental protection and safety in European seas.

\section{PRE-CLEARANCE: THE DECLARATION AT SEA}

Article 7 of the WTO Agreement on Trade Facilitation (TFA), highlights the importance of simplification and harmonization of customs procedures in order to save time, stating that "each Member shall adopt or maintain procedures allowing for the submission of import documentation and other required information, including manifests, in order to begin processing prior to the arrival of goods with a view to expediting the release of goods upon arrival".

As far as maritime transport is concerned, the declaration at sea is an attractive opportunity for the main maritime transport stakeholders, such as shipping companies, terminal operators and intermodal operators. Through the declaration at sea procedures, goods can be cleared at sea before being unloaded from sea-going vessels. In fact, when vessels arrive at the harbour of destination, goods on board are already cleared and ready to be released, thus the transit time of containers inside ports is reduced. The possibility of clearing goods before the arrival of vessels at the port improves the efficiency of the international supply chains and reduces the storage time of containers, accelerating the handling operations. This has a favourable impact on avoiding the possibility of container congestion at harbours. More to the point, preclearance reduces the risks of demurrage charges for the importer, as demurrage charges are levied by the shipping line to the importer if the container is not moved out of the harbour terminal within the deadline decided by the shipping line.

Concerning the EU customs legislation, Article 133 of Regulation 952/2013, which is the EU customs code currently in force, along with Regulation 648/2005 and the Reporting Formalities Directive (Directive 2010/65/EU) [10], examine the matter of sea-going vessel arrival notification. In particular, with regard to the notification prior to arrival into ports, Article 4 of Directive 2010/65/EU underlines that Member States are required to "ensure that the master or any other person duly authorised by the operator of the ship provides 
notification, prior to arriving in a port situated in a Member State, of the information required under the reporting formalities to the competent authority designated by that Member State: (a) at least 24 hours in advance; or (b) at the latest, at the time the ship leaves the previous port, if the voyage time is less than 24 hours; or (c) if the port of call is not known or it is changed during the voyage, as soon as this information is available". Furthermore, Article 7 of Directive 2010/65/EU requires that EU Member States accept FAL forms for the fulfilment of reporting formalities.

The list of documents to be presented 24 hours before the arrival can be summed up as follows: ship's pre-arrival security information form (ISPS); FAL form 2 (cargo declaration); FAL form 5 (crew list); FAL form 6 (passengers list); FAL form 7 (dangerous goods and waste). Two hours prior to the arrival, documents to be presented are: IMO general declaration FAL 1, FAL form 3 (Ship's Stores Declaration), IMO crew effects declaration FAL 4 and health declaration. However, Directive 2010/65/EU underlines that if ships operate between ports of the EU customs territory should be exempt from the obligation to send the information referred to in the FAL forms.

In the European Union, the pre-clearing pilot project was implemented in the Italian harbours of Genoa and La Spezia during 2014 [11], [12].

Obviously, the pre-clearing mechanism can only work effectively if economic operators are able to understand and comply with customs regulation and are able to deal with document-related customs controls. Specifically, inside the European Union, customs authorities must be informed about the customs procedures to apply when non-EU goods enter the EU customs territory. In this regard, Article 5 of Regulation 952/2013 states that "customs procedure means any of the following procedures under which goods may be placed in accordance with the Code: (a) release for free circulation; (b) special procedures; (c) export". Concerning the release for free circulation, Article 201 of Regulation 952/2013 underlines that Custom authorities are authorised to collect any import duty due (and any other charge) on non-EU goods intended to be brought into the EU internal market as well as to apply commercial policy measures and prohibitions or restrictions. In addition, the EU customs legislation, specifically Article 127 of Regulation 952/2013, requires that any type of merchandise entering the EU customs territory must be covered by the ENS (Entry Summary Declaration).

Last but not least, the documents necessary to clear goods must contain detailed information concerning the quantity, the origin and the value of the goods as well as the description of the merchandise in order to classify goods in line with the harmonized system (HS), which is a world-wide-recognized 6-digit classification code. It is worth underlining that the advantages of the pre-clearing mechanism are increased if the economic operators involved in the import operations have obtained the status of Authorised Economic Operator (AEO).

\section{AEO: AN ADDED VALUE FOR PRE-CLEARANCE}

The AEO status allows economic operators to benefit from reduced numbers of customs authorities controls and more rapid processing of goods. The AEO-rule mechanisms, which are based on the simplification and harmonization of customs formalities, are intended to make international trade flows faster by reducing physical and safety-related inspections and by lowering the number of document-based customs controls.

All economic operators involved in the worldwide supply chain mechanisms (e.g. exporters and importers, freight forwarders, warehouse keepers, storage facility operators, customs agents, carriers, logistics and terminal operators, stevedores, and cargo packers) can apply for the AEO status. In line with the AEO formula, economic operators 
are required to adhere to legal disciplines on quality criteria and are encouraged to cooperate with customs authorities in order to fulfil safety criteria and harmonized procedures established by customs authorities.

The AEO status allows the economic operators to obtain both direct advantages in terms of safety inspection simplification and reduced document-based customs controls, and indirect benefits, mainly in terms of limiting the risk of delayed shipments and the risk of theft and losses. International economic operators have the opportunity to acquire two types of AEO status:

I) AEO-C, which enables the holder to benefit from simplifications in accordance with the customs legislation.

II) AEO-S, which deals with security and safety and entitles the holder to facilitations pertaining to security and safety.

Concerning the EU legislation, the AEO was introduced by Regulations 648/2005 and 1875/2006. In addition, Articles 38 and 39 of Regulation 952/2013 point out the main criteria for granting the AEO status: the absence of repeated or serious infringement of customs legislation; the demonstration of full control of the flow of goods and of transport records; proven financial solvency, principally the applicant must not be subject to bankruptcy proceedings; appropriate security and safety standards, mainly to be met in case of AEO-S applications. In this regard, it is worth noting that AEO compliance criteria are valid instruments in order to reduce the time required for clearing goods as well as to implement the pre-clearance mechanism effectively.

\section{CONCLUSIONS}

In order to develop a geographic area in terms of international trade and global competition, three aspects must be taken into consideration: infrastructures, services and technology. The efficiency of customs depends on several economic factors; however, a well-organized network of roads, ports and airports is a milestone. In this regard, the so-called "fast corridors" are a valid logistics solution. In fact, fast corridors, making use of technological instruments such as Radio Frequency Identification (RFID), Global Position System (GPS) and Optical Character Recognition (OCR), facilitate the efficient flow of cargo in supply chains, thus import cargo to be transferred from ports to the final destination in a "controlled" corridor. In Italy, the fast corridor of port of Ravenna is an interesting pilot project, which involves three gates connecting the port to the main rail and road networks. In addition, a proper use of technology (i.e. e-customs) is essential for customs procedures simplification and harmonization, and for the reduction of administrative burden [13], [14].

The customs operations within the EU ports can be faster and the movement of goods facilitated through the implementation of the national single windows as well as the exchange of electronic information between customs authorities in the EU territory. Any delay brings about additional costs for economic operators, especially in terms of storage costs and penalties. For instance, Customs 4.0 allows the combination of digital transformation and supply chain and logistics processes improvement. According to the statistics data provided by the Italian Customs Authority (Agenzia delle Dogane e dei Monopoli) for the year 2016, thanks to e-customs and the use of technology (electronic files), in the main Italian harbours, on average, the percentage of goods cleared within 5 minutes was $84.3 \%$ during the first four months of 2016 and $92.6 \%$ from May until December 2016. The percentage of customs clearance declarations, which were processed within 5 minutes reached $96 \%$ in the port of Venice - this was the highest performance level among the Italian harbours in 2016. Brindisi, Genoa, La Spezia, Leghorn and Trieste 
were also efficient ports in terms of fast customs-related operations: on average $85 \%$ of imported goods were cleared within 5 minutes [15]-[17].

In this regard, it is necessary to underline that the port of Venice has implemented a web-based Information Technology platform called LogIS (Logistics Information System), which aims to improve and speed up the document workflow management. The LogIS allows economic operators, such as shipping agents, freight forwarders, terminal operators, as well as the Harbour Master to share information more effectively, especially with third party software applications (e.g. EDI - Electronic Data Interchange). The LogIS platform consists of five modules: a ship module, which deals with both the documents necessary to enter (or call at) the port of Venice and the shipping processes; a cargo module pertaining to the details about loading and unloading goods at the terminals; a security module; a port labour module to control workers' data; and finally a module for on line applications [18].

A customs union like the EU will be increasingly attractive for global players and economic operators if customs administrations are well-organized and goods can be released rapidly instead of being stuck at ports once unloaded from vessels, allowing the decongestion of harbour areas.

Concerning the impact of IT on customs-related operations, it is also worth mentioning that in April 2019 the Danish integrated container logistics company Maersk started a new e-customs project introducing the digital ocean customs clearance. This project has allowed Maersk to activate a customs clearance online shipping management platform in seven EU countries (France, Germany, The Netherlands, Poland, Spain and the United Kingdom).

[1] Gormley, L.W., EU Law of Free Movement of Goods and Customs Union, Oxford University Press: Oxford, 2009.

[2] Mikuriya, K., Supply chain security: The customs community's response. World Customs Journal, 1(2), pp. 51-59, 2007.

[3] ICC, Explanatory notes to guideline 9 of the International Chamber of Commerce (ICC) customs guidelines.

[4] World Customs Organization, Punta Cana Resolution: Resolution of the Policy Commission of the World Customs Organization on the role of customs in the security context, 2015.

[5] World Customs Organization, WCO SAFE Framework of Standards, p. 2, 2018.

[6] Shipping Federation of Canada, Chapter VI-A, Regulation 2 of the SOLAS.

[7] UN/CEFACT, Recommendation and Guidelines Establishing a Single Window to Enhance the Efficient Exchange of Information Between Trade and Government, Recommendation 33, ECE/TRADE/352, New York and Geneva, p. 3, 2005.

[8] European Commission (Directorate General for Mobility and Transport), National single window: Guidelines, final version, 2015.

[9] European Union, National single window data mapping report, Version 1.8, 4 Dec. 2018.

[10] European Union, Directive 2010/65/EU of the European Parliament and of the Council of 20 Oct. 2010 on reporting formalities for ships arriving in and/or departing from ports of the Member States and repealing Directive 2002/6/EC, 2010.

[11] Malaguti, P., Il Preclearing: Nuove possibilità nel trasporto merci con lo sdoganamento in mare. Italian Maritime Journal, 2, pp. 8-10, 2015;

[12] Orsi, G., The Union Customs Code and innovation in Italian customs procedures. Global Trade and Customs Journal, 12(2), pp. 68-73, 2017. 
[13] De Wulf, L. \& Sokol, J.B. (eds), Customs Modernization Handbook, The World Bank: Washington, pp. 285-310, 2005.

[14] Vaghi, C. \& Lucietti, L., Costs and benefits of speeding up reporting formalities. Transportation Research Procedia, 14, pp. 213-222, 2016.

[15] Agenzia delle Dogane e dei Monopoli, Organizzazione, attività e statistica, p. 35, 2016.

[16] Agenzia delle Dogane e dei Monopoli, Libro Blu, p. 37, 2017.

[17] Camera dei Deputati (Italian Parliament Deputies Chamber - Commission for digital innovation of Public administrations), La nuova Dogana, ovvero come usare l'innovazione tecnologica per coniugare la tutela e la competitività del mercato, pp. 4-5, 2017.

[18] Venice Port Authority, LogIS (Logistics Information System). The Port Community System of Venice. www.port.venice.it/files/page/presentationlogiseng09032015.pdf. 